\title{
Role of Organizational Culture on the Performance Primary School Teachers
}

\author{
Suharningsih $^{1} \&$ Murtedjo $^{2}$ \\ ${ }^{1}$ PPKN department, Faculty of Social Sciences and Low, State University of Surabaya, Surabaya, Indonesia \\ ${ }^{2}$ Geography Education Department, Faculty of Social Sciences and Low, State University of Surabaya, Surabaya, \\ Indonesia \\ Correspondence: Priyono, Post Graduate Management Program, University Bina Darma Palembang, Indonesia. \\ E-mail: priyono.unu_sidoarjo@yahoo.com
}

Received: September 13, 2016

Accepted: October 20, 2016 Online Published: November 10, 2016

doi:10.5539/jel.v6n1p95

URL: http://dx.doi.org/10.5539/jel.v6n1p95

\begin{abstract}
This study aims to identify and examine the role of organizational culture on teacher performance.

In the present study examined the role of organizational culture with teacher performance. In accordance with the study design, namely the survey, the data collected in this research is quantitative data. The data is extracted and obtained through the views of teachers through questionnaires. To test the hypothesis formulated likert scale instrument is required to generate the data interval.

These results indicate there is no significant effect between Organizational Culture on Teacher Performance. The value of the coefficient is positive, which means that the better the organizational culture will lead to better teacher performance, and vice versa, the less good organizational culture will lead to a decrease in teacher performance. Role between the two is not significant, because it has a relatively weak role as well as through other variables.
\end{abstract}

Keywords: organizational culture, performance, elementary school teacher

\section{Introduction}

Expectancy theory of Vroom directed specifically how does a leader motivate their employees, in order to improve its performance. For a leader of the performance improvement achieved by the employees is an indication of the success of the organization he leads.

Performance comes from the word that means the performance of what is done, how to do, and the results achieved from such work. In modern management, including management education, a person's performance is strongly influenced by the work spirit, climate conducive communication between leaders and subordinates in relation to performance. The essence of communication performance include morale, status in employment, opportunities in employment and confidence.

Performance is basically a performance that was pursued achievement of work to produce a particular outcome at a predetermined time. Performance is a combination of behavior with the achievement of what is expected and the choice or part of the terms of an existing task on each individual in the organization. Performance is the result of the quality and quantity of work that can be achieved by a worker in carrying out duties in accordance with the responsibilities given to him (Mangkunegoro, 2001; Cascio, 1995; Armstrong, 1998).

From the understanding of the performance can be concluded that in principle the performance is a multidimensional construct that includes many factors that influence it. Factors that affect performance factor may be mentioned, among others, personal, leadership, team, system, contextual (Mahmudi, 2002). In this regard Campbell (1990) states that a functional relationship with the performance attributes of the attribute, is influenced by three main factors namely knowledge, skills and motivation. Knowledge refers to the knowledge held by employees, related to the knowledge of what they will do (knowing what to do). Skills refers to the ability to do the job, while the motivation is the encouragement and enthusiasm to do the job so get the rewards in the form of reward. 
The best chances for workers to achieve peak performance, both at the individual, team or organization lies in the strategy-making performance management system and providing feedback as soon as possible as to how effectively they work. This feedback is a means to enter a more productive future.

Feedback from performance measurement results, are intended to reach their potential, every employee is not enough to just do, but must act in accordance with the results of the assessment and management must help employees to improve themselves in the future. Employees who sincerely wants to improve its performance, has the responsibility of looking for honest feedback and utilize it to improve its performance.

Designing performance management to maximize the performance will not guarantee more perfect, but it should improve the system performance, so that satisfaction with the system may be increased (Reddin, 1989). And provide clear criteria for employees to do the job in a labor organization.

Redefining Cultural Organization as the fundamental basis for an organization is considered very necessary, because the cultural meaning in life is the perception and all attitudes that arise from the interaction of a person with his work, with others and with the environment. By that Gordon and Ditomaso (1992) provides a definition of organizational culture is: an organizational culture is the shared attitude and perseption in an organization that a base on a set of fundamental norms and values and help members understand the organization. Organizational Culture is all the attitudes and perceptions that arise as a result of the interaction of a person with his work, with others and with the environment, attitudes and perceptions that arise in the organization comes from a set of values and norms that help member organizations to understand all the aspects related to the the place of work.

Organizational culture is a strength, in the organization that are not visible, but can be felt and perceived by its members. The results of these perceptions affect the behavior of its members in carrying out the work. In this case Robbins (2007) explains that: organization culture is a perception, but is exist in the organization, not in the individual. As a result, individuals with different backgrounds or at different levels in the organization growing niche to describe the organization culture in the smilar terms.

Lunberg and Martin (1991) a definition of organizational culture as follows: organization culture occasionally, coled organization climate, is the set of assumptions, bieliefs, values and norms that is shared Among its members. It is the human environment provider in the which employes perform Reviews their job. Cultural organizations often also called organizational climate, is a number of assumptions, beliefs, values, and norms that are owned by members of the organization. Organizational culture is in the work environment and the organization's members may establish or affect their behavior in the work.

From the definition above show that organizational culture has the same nature and purpose. Thus the organizational culture can be described as a system of values, norms, way of life, beliefs and attitudes held by members of the organization. All aspects of the organizational culture can influence and shape the behavior of its members in carrying out the tasks of the organization.

A strong organizational culture is reflected by employees with a clear understanding of the system of shared meaning held by members, so as to distinguish a particular organization with other organizations.

The organization as a culture, is an organization where there is a system of values shared by its members. This view is a new paradigm of organizational culture, where previously the organization solely as a tool for coordinating and controlling a group of people. However, the organization is actually more than just a tool to control and coordinate a group of people. Organizations have different personalities, for it was then the organization can be rigid or flexible, not friendly or supportive, innovative or conservative. Organizational culture is a system of shared meaning held by members that can distinguish between the different organizations. The system of shared meaning is the set of characteristics that are valued by the organization. A set of these characteristics include: (a) Innovation and risk-taking; (b) Attention to detail; (c) Results orientation; (d) aggressiveness; (e) Steadiness (Robbins, 2007). For that organization should be treated as cultured behavior so as to have a role in the development of the organization.

Today theory recognize that the organization has a role for its members when the organization has experienced institutionalization. If the organization is institutionalized, then that organization has a life of its own so that the organization was rewarded for himself, not only on goods and services produced.

Institutionalization was taking place in an attempt to produce a common understanding among its members about what behavior is appropriate and meaningful to him. So if the organization becomes permanent institution, then the acceptable behavior of their members to be very clear. These steps are substantially similar to the steps undertaken by the organization's culture. Thus understanding what form the organizational culture, how culture is created, 
learned and maintained, will improve the ability of a person in the organization so that it can improve a person's ability to explain and predict the behavior of people in their work environment.

In everyday life, a person will not be separated from the work environment. A person's personality will be formed also by the environment and that these personality leads to positive attitudes and behaviors that must be supported by a recognized norms of truth and obeyed as a guide in the act. Basically, humans or someone who is in the life of an organization seeking to determine and establish something that can accommodate the interests of all parties, so that in carrying out its activities do not clash with the attitudes and behavior of each individual. Something in question is none other than a culture where people are located, such as values, beliefs, assumptions, expectations, and so on.

In the organization, implementation constituti culture in the form of behavior, meaning that the behavior of individuals in the organization will be colored by the culture of the organization concerned. Individual behavior with regard to real actions committed by a person who can be interpreted that in doing one's actions will definitely not be separated from his behavior. Goal-oriented behavior in organizations coordinated cultured. An organizational culture that is understood by all members can encourage work effectiveness. An organizational culture that can drive the effectiveness of the work exhibited in innovation and risk taking, attention to detail, results orientation, aggressiveness and stability.

To achieve high employee performance can not be separated from the influence of organizational culture, because the culture of the organization is a part of organizational life that affect the behavior, attitude and effectiveness of employee (Hofstede, 1990); Limberg and Martin (1991) Organizational culture is a strength in the organization that are not visible, but can be felt and perceived by its members. The results of these perceptions influence the behavior of their members to do the job. Goal-oriented behavior coordinated role in organizational culture encourages the effectiveness of the work, which was exhibited in innovation and risk taking, attention to detail, results orientation, aggressiveness and steadiness (Robbins, 2007). Thus, the relationship between organizational culture with the teacher's performance lies in the effectiveness of the work. Issues arising from the foregoing description is how much influence between organizational culture on employee performance.

\section{Research Methods}

In the present study examined the role of organizational culture with teacher performance. In accordance with the study design, namely the survey, the data collected in this research is quantitative data. The data is extracted and obtained through the views of teachers through questionnaires.

Questionnaires were distributed in this study as many as 200 copies, more than is needed. This is done to anticipate possible questionnaires are not returned or damaged. Of questionnaires collected as many as 190 copies, considered sufficient than the amount specified in the analysis of a number of 174 copies.

Questionnaires collected from the respondent characteristics can be identified by gender, age, rank/grade and level of education. Based on respondents' gender research there are 69 or $39.7 \%$ of male respondents and 105 female respondents, or $60.3 \%$. Based on the age of survey respondents with an average age of 45 years, with the youngest 30 and the oldest 59 years of age. Respondents with type II some 15 people or $8.62 \%$; class III number of 139 persons or $79.89 \%$, and respondents with type IV number 20 ata $11.49 \%$. Based on the level of education possessed by the respondents, 157 people or $90.23 \% \mathrm{~S} 1$ degree (undergraduate) and 17 people or $9.77 \%$ degree D3 (Diploma three).

To test the hypothesis formulated Liekert scale instrument is required to generate the data interval. This type of research that is selected is a survey research with multiple Correlation, in order to explain the relationship between organizational culture with the performance of teachers (Biener \& Lyberg, 2003; Creswell, 2009). In connection with this, the analytical technique chosen is the technique of path analysis (path analisys) (Solimun, 2002), because it is consistent with the approach chosen, the type of research and analysis techniques used and the objectives to be achieved in this study.

\section{Research Result}

In this paper will explain the role of organizational culture on teacher performance. In accordance with the study design, the necessary data is quantitative data with a certain interval. Data collected through the views of teachers through questionnaires.

The questionnaire data retrieval as much as be used in 200 copies. Of questionnaires collected as many as 190 copies, considered sufficient for analysis only requires as many as 174 copies of questionnaires. 
Of questionnaires collected, the characteristics of the respondent may be identified by gender, age, rank/class and level of education that has been achieved. Based on respondents' gender study consisted of 69 male respondents $(39.7 \%)$ and 105 female respondents $(60.3 \%)$. By the age of survey respondents, the average age of 45 years, with the youngest aged 30 and the oldest 59 years of age. Respondents with some 15 class II, class III some 139 people and respondents with category IV number of 20 people. Qualification owned by the respondents, 157 respondents with education level S1 and 17 respondents with education level D III.

From the results of the collection of data obtained through the above-mentioned respondents reflected on the role of organizational culture variables and teacher performance. Measurement of study variables using a scale of 1 to 5 on a Likert scale. The frequency distribution of the organizational culture of the 174 respondents to the interval class 5 , the highest score of 100 and the lowest 60 with a range of 40 , in order to obtain class intervals for five categories of 8 .

The description of the organizational culture frequency indicated by 174 respondents who believe that organizational culture has been very good working environment there are as many as 30 respondents $(17.2 \%)$, with a score interval 92-100, 63 respondents (36.2\%) found organizational culture in their work environment is quite good with a score interval $84 \leq 92 ; 74$ respondents $(42.5 \%)$ stated that the organization's culture in their work environment is good enough to score the interval $76 \leq 84$, while seven respondents declare that organizational culture brackish unfavorable work environment.

While the frequency distribution of teacher performance, of the 174 respondents to the interval class 5 , the highest score of 50 and the lowest score 30 , so the range is 20 , in order to obtain class intervals for five categories of 4 . Of the 174 respondents who stated that the performance of teachers in their work environment have been classified very high, as many as $46(26.4 \%)$, with a score of $46-50$ interval; $58(33.3 \%)$ of respondents believe that the performance of teachers in their work environment is already quite high with the score interval $42 \leq 46 ; 62$ respondents (35.6\%) stated that the performance of teachers in their work environment is classified, and the rest is that the performance of teachers in their work environment is low.

Role of Organizational Culture on teacher performance is described by the path coefficient of 0.066899 (coefficient is positive), showed the value of the $t$ statistic of 0.903617 , which is under \pm 1.654 (alpha $=10 \%$ ), so it can be concluded that there is no effect significant between Organizational Culture on Teacher performance. The value of the coefficient is positive, which means that the better the organizational culture will lead to better teacher performance, and vice versa, the less good organizational culture will lead to a decrease in teacher performance. Role between the two is not significant, because it has a relatively weak role as well as through other variables.

\section{Discussion}

Based on the categorization of variables Organizational Culture, Organizational Culture is known that the level of most of the schools (42.5\%) are in good enough category, the remaining $17.2 \%$ are in the very good category, $36.2 \%$ in both categories, the remaining $1.1 \%$ poor and $2.9 \%$ are not good.

Organizational culture as a system of shared meaning held by members of its members, which distinguishes the organization with organizations that her other (Robbins, 2007). Shared meaning system established by its members is a key character set of values that is understood by the teacher organizations, school organizations being personable.

In the context of this paper is implemented in the organization of cultural activities of the learning process. In any teacher initiated learning activities teachers write lesson plans, and implement lesson plans that have been made and ends with the assessment/evaluation. As noted by Banghart and Trulli (1973) in Majid (2008), planning is the beginning of all rational process and contains optimism based on trust that it will be able to overcome the various problems that arise in each learning activity. Planning is a systematic process of making decisions about actions to be taken in time to be dating as foundation planning exercise that has formulation.

Implementation of the lesson plan is defined as a process that is done in guiding and directing the participant students to have the experience of learning, both cognitive, affective and psychomotor (Sumantri, 1988). Another important component of which is the assessment/evaluation.

Evaluation is a systematic process of collection, analysis, interpretation of data information to determine the extent to which learners have achieved the objectives/master competencies (Grondlund, 1981; Gilbert, 1985; Guba \& Lincoln, 1985).

Based on the description above it can be concluded that the School Organizational Culture is a reflection of a large part of teacher work culture in the category quite well. This means that the teachers of primary school teachers 
have to understand what must be done, and how to implement, as well as how to evaluate it. This condition will support the effectiveness and efficiency of teacher performance.

Based on the categorization Variable teacher performance, it is known that the performance of the majority of primary school teachers $(35.6 \%)$ are in the medium category, the remaining $33.3 \%$ were in the high category, $26.4 \%$ in the category of very high, $2.3 \%$ in the category lower and $2.3 \%$ are in the very low category. The performance of teachers in this context still shows the condition that always gets attention though has been at condition pretty good. It is understandable that the performance of teachers is one of the important indicators related to achievement levels that can be achieved and reflects the success in learning and reflects the behavior of members of the organization can be generated (Gibson, 1988).

Based on the description above can be concluded that the performance of teachers of primary school teachers in the implementation of learning is good enough, because the role of the teacher in learning is very central and determining educational success it is necessary to get attention (Suharningsih, 2009).

By using the technique of path analysis, it can be seen that the path coefficients in the path of the first relationship constructs organizational culture shows positive and significant relationship to the construct of job satisfaction. Then the path coefficients in the path of the relationship between both constructs job satisfaction, showed a positive and significant to construct the performance of teachers. Thus it can be said that the organizational culture has a positive role though indirectly of teacher performance through job satisfaction.

Organizational culture/work culture, the dominant values are disseminated within the organization and as a philosophical reference for teachers in the teachers' work (Djokosantoso, 2003; and Sutanto, 1997). Thus Organizational Culture as values that guide the human resources to face the issue of external problem and business integration into the work environment so that each member organization must understand that there are values as basic act or behave.

The key character of the Cultural Organization as to which is described by Robbins (2006) includes: (a) innovation and the courage to take risks, it implies the extent to which the organization encourages members to be innovative and have the courage to take risks in many ways related to their job. Moreover, how organization appreciate every act of risk-taking and generate ideas for any teacher; (b) the attention to detail. Is the extent to which the organization expects his employees analysis shows the accuracy of the details. Implementation in the organization of the school include supervising and monitoring the execution of system administration requirements learning activities; (c) oriented towards results. In the day to day management action attention focus on techniques and processes used to achieve results. Applications in school organization focused on the evaluation of teaching duties by the manager and the evaluation of learning outcomes by the teacher; (d) aggressiveness, is the extent to which people in the organization and competitive agrsif to run the organization's culture as best as possible. Implementation in school organization, teacher encouragement to teachers to achieve optimum productivity; (e) Stability, is the extent of the organization's activities emphasize the status quo as to which results have been achieved. Implementation in schools among other organizations reward teacher performance by principals prioritized efforts on individual efforts.

Theoretically Cultural Organization has a role on the performance of teachers, through the Job Satisfaction, where a culture, providing guidance to the teacher how she perceives the characteristics of the culture of an organization as a value that is required in the work, interact with their peers, with the system and administration, as well as interacting with his boss.

Using the approach of Human Resources, Karl (2001) explains that organizational culture has an influence on job satisfaction. The better the Organizational Culture will increase job satisfaction. It is supported by the results of research Ronnga (2001), Alexander and Luthans (1997) which states that in result Cultural Organization effect on job satisfaction.

The relationship between job satisfaction with the performance can be explained by the theory of "Flow", expressed by Mihaly Csikzentmihalyi (in Goleman, 2007). Flow is a state free from emotional disturbances and away from coercion, feeling full of emotion caused by ecstasy light. Flow allows people handle challenging tasks in a particular field. The key state of flow is only happening within reach peak capability, where the skill has been trained well. The end of the flow condition is the satisfaction of their work. A high level of satisfaction that will affect performance. It can be concluded that there is influence job satisfaction between premises although performance through other variables. 
Supported research results from Fisher (2000) and Rafaeli and Sutton (1989), which in presentation explaining that job satisfaction is associated with emotions of workers both positive emotions and negatife seen in the expression of emotions in organizational life.

\section{Conclusion}

Employee performance is an indicator of the level of achievement that can be achieved by the employees and reflects the success of a leader in organization. This success will have an impact on the performance of employees in their fields respectively.

Employee performance can be affected by many variables, including Organizational Culture and Job Satisfaction. Organizational Culture indirect effect on employee performance through job satisfaction. This may imply that there is a direct and positive relationship between the construct of Organizational Culture with Employee Performance through Employee Satisfaction constructs. The coefficient of correlation is positive, this means that the better the organizational culture, the higher the Employee Satisfaction and the higher the Employee Performance. Thereby otherwise getting worse Cultural Organization, the lower job satisfaction gained by employees and this will affect the further weighed employees performance.

\section{References}

Armstrong, M. (2004). Performance Management (T. Setiawan, Trans.). Yogyakarta, Tugu.

Beach, L. R. (1993). Making The Right Decision Organizational Culture, Vision and Planing. United States of America: Prentice-Hall Inc.

Bliss, W. G. (1999). Why is Corporate Important. In An Introductory Text Organizational Behavior (3rd ed.). Europe: Prentice Hall.

Campbell, D. (1990). The Force of Prajudice. The Guardian.

Cascio, W. F. (1995). Managing Human Resources: Productivity, Quality of worklife, Profits (4th ed.). Singapore: McGraw Hill Inc.

Cavity, K. L. (2001). Human Resources Practices. Organizational Climate and Employee Satisfaction. Academy of Management Review, 619-644.

Creswell, J. W. (2010). Research Design, Qualitative, Quantitative, and Mixed Approaches metods (3rd ed.). Sage publication.

Djokosantoso, M. (2000). Corporate Culture and Corporate Excellence. Jakarta, Alex Media Komputindo.

Fisher, D. (2000). Man and While Working: Missing Place of Job Satisfaction. Journal of Organizational Behavior, $21, \quad$ 185-202. http://dx.doi.org/10.1002/(SICI)1099-1379(200003)21:2<185::AID-JOB34>3.0.CO;2-M

Gibson, J. L. et al. (2000). Organization. Boston, McGraw-Hill Book, Companees, Inc.

Glaciers et al. (1987). Measuring and Interpreting Organizational Culture. Management Comunication, 1(2) 173-178.

Goleman, D. (2007). Social Intelligence. Science of Human Relationships (S. Hariono, Trans.). Jakarta PT, Gramedia Pustaka Utama.

Gordon, G. G., \& Ditomaso, N. (1992). Predicting Corporate Performance From Organizational Culture. Journal of Management Studies, 793-798. http://dx.doi.org/10.1111/j.1467-6486.1992.tb00689.x

Hofstede, G. (1986). Cultur's Consequences, International Differencess in Work Related Value. SAGE publikcation, Beverly Hills/London/New Delhi.

Kartono, K. (1994). Social Psychology for Management Companies and Industry. Jakarta, King Grafindo Persada.

Kotter, J. P., \& Heskett, J. L. (1992). Corporate Cultur and Performance. New York: The Free Press, a devision of Mac Millan, Inc.

Kreitner, R., \& Kinicki, A. (1995). Organizational Behavior (3rd ed.). Printed in The United State of America: Richard D. Irwin Inc.

Linberg, C. C., \& Martin, J. (1991). Reframing Organizational Culture. New Bury, Park, CA. SAGE Publicating.

Mahmudi. (2007). Public Sector Performance Management. Yogyakarta, High Seklah Management Sciences, YKPN. 
Mangkunegoro, A. A., \& Anwar, K. (2001). Human Resource Management Company. Bandung, PT. Teens Rosdakarya.

Molenaar, K. (2002). Corporate Culture, A Study of Firm With Outstanding Consideration Safety (pp. 18-27). Prosesional Safety.

Rafaeli, A., \& Sutton, R. I. (1989). The Expression of Emotion in Organizational Life. Organizational Research, $11,11-42$.

Robbins, S. P. (2007). Organizational Behavior. Edition Indonesian, Jakarta, PT. Index.

Solimun. (2002). Structural Equation Modelling (SEM), lisrel and Amos. Malang State University.

Sutanto, A. B. (1997). Corporate Culture: Series Management and Business Competition. Jakarta Elex Media Kompetindo, Reframing Organizational Culture.

\section{Copyrights}

Copyright for this article is retained by the author(s), with first publication rights granted to the journal.

This is an open-access article distributed under the terms and conditions of the Creative Commons Attribution license (http://creativecommons.org/licenses/by/4.0/). 